in one solvent and molecularly dispersed in another. In the photo-chemical field he obtained by elegant methods condensations of hydrocarbons with aldehydes and ketones; he succeeded in preparing a number of synthetic alkaloids and was able to throw light on the probable mechanism by which plants produce many of these compounds.

In addition to his research activities, Paternò excelled as an organiser. He founded and edited the Gazetta Chimica Italiana. In Palermo he was both principal of the University and mayor of the City, and in Rome he occupied many Government positions. A gold medal was founded in 1923 in his honour, to be given every three years for the most notable discovery in chemistry, the first award being made in the same year to Dr. F. W. Aston. Prof. Paternò was elected an honorary fellow of the Chemical Society in 1920 .

SiR WILliam Morris, K.c.M.g., c.B.

WE regret to record the death of Sir William G. Morris on February 26, in North Wales. $\mathrm{He}$ was a man beloved by all who had the privilege of knowing him. Born in 1847, he entered the Corps of Royal Engineers in 1867. After various home duties he went to Mauritius in 1871 and remained there until 1874, the year of the transit of Venus expedition to that island, with which the names of Lord Lindsay and Sir David Gill are so intimately associated. This appears to have marked the beginning of that collaboration with Gill which was later to have such useful results in South Africa; for after a spell of two years at the Staff College and later at home duties--particularly as assistant instructor in survey at the School of Military Engineering, Chatham, from 1877 until 1882--he was acting on special duty in 1882-83 under the Transit of Venus Committee at home and abroad.

At this juncture, Sir David Gill, who was then H.M. Astronomer at the Cape of Good Hope, had succeeded in persuading the Governments of Cape Colony and Natal to undertake a geodetic survey of their territories. To carry out this work Gill naturally turned to Morris, who after two months work on special duty under the Colonial Office, became the leader of the Geodetic Survey of the two Colonies, an undertaking which absorbed his energies for ten years. Officially he was noted for special duty under the Government of Natal, which was the first of the two Colonies to support Gill's proposal for the geodetic survey. This work, indissolubly associated with the names of Gill and Morris, was the beginning of the Great Are of the 30th Meridian which last year was carried to the Belgian frontier of the two provinces of Ruanda and Urundi.

On his return home, Morris received the C.M.G. for his services on the geodetic survey of the Cape and Natal. He next went to Chatham and in the period 1895-98 was assistant commandant of the School of Military Engineering; but South Africa was calling, and he returned there in 1898 as Colonel on the Staff, C.R.E., acting as district engineer during the South African War (1899-1902). He was twice mentioned in dispatches and received various honours and the C.B. After the war an occupation doubtless more congenial to his nature was in store for him : in 1902 he became officially superintendent of the Geodetic Survey of the new territories, and in 1906 completed the principal triangulation of the Orange River Colony (as it then was) and the Transvaal. He retired from the Army on half pay in 1904 and for the last thirty of his long spell of eighty-eight years lived very quietly on a mountain-side overlooking Bettws-y-Coed. Visiting him there about three years ago, the present writer found that his mind had apparently drifted beyond South Africa, the scene of his former triumphs.

Gill and Morris built up in South Africa a fine school of geodesy. Supported by able assistants, they established a tradition which has not been without effect on the world at large. Mr. Victor A. Lowinger, one of these assistants, writes: "Morris was devoted to his work and inspired all who worked under him with the value of thoroughness and accuracy. He chose his men carefully and trusted them to get on with the job, while at the same time he was always ready to resolve any difficulties that arose. He was of a very reserved nature and, though a little intolerant of human weaknesses, very just in his judgments - a man with whom one has been proud to have been associated in one of his great practical contributions to geodesy." G. T. M.

\section{Mr. M. V. Portman}

WE regret to record the death of Mr. Maurice Vidal Portman, which occurred at Axbridge, Somerset, on February 14, at the age of seventy-four years. Mr. Portman was well known as an authority on the natives of the Andaman Islands as they existed fifty years ago. He was appointed "Officer in charge of the Andamanese", with headquarters at Port Blair, in 1879, and remained in the Andamans until 1899, when he was sent home on account of ill-health. Throughout his term of duty he was in constant and intimate touch with the life of these tribes of shy, difficult and sometimes dangerous, little people. As a result of his care for them and his disregard for the risks he ran in getting into touch with them, he acquired knowledge of their customs and beliefs which made him the equal, if not indeed the superior, as an authority, of F. H. Man, although the latter won the wider reputation through his books. Mr. Portman was a contributor of papers on Andamanese matters to the publications of learned and scientific societies, and made a remarkable collection of photographs of the Andamanese and their articles of material culture.

WE regret to announce the following deaths :

Sir John Rose Bradford, K.C.M.G., C.B., C.B.E., F.R.S., emeritus professor of medicine in University College, London, president of the Royal College of Physicians in 1926-31, on April 7, aged seventy-one years.

Prof. E. Cannan, emeritus professor of political economy in the University of London, on April 8, aged seventy-four years. 